\title{
Penerapan Lidah Buaya Untuk Penyembuhan Luka Diabetik
}

\author{
Anik Enikmawati $^{1}$, Muhammad Hafiduddin ${ }^{2}$ \\ Prodi DIII Keperawatan, ITS PKU Muhammadiyah Surakarta \\ ${ }^{2}$ Prodi DIII Keperawatan, ITS PKU Muhammadiyah Surakarta \\ Email :*anikenikmawati@gmail.com
}

\section{Kata Kunci \\ Diabetes Mellitus, Lidah buaya, Luka diabetik}

\begin{abstract}
Abstrak
Ulkus kaki diabetik(UKD) sampai saat ini menjadi masalah kesehatan utama di Indonesia, kasus ini semakin meningkat, Luka bersifat kronis dan sulit sembuh, mengalami infeksi dan iskemia tungkai dengan risiko amputasi. Bila tidak ditanggulangi, Kondisi ini dapat menyebabkan penurunan produktivitas, disabilitias, dan kematian dini. Tujuan penelitian ini adalah untuk mengetahui bagaimana pengaruh ekstrak lidah buaya terhadap proses penyembuhan luka diabetik pada penderita diabetes mellitus. Penelitian ini merupakan quasi ekperimen dengan pre - post test one group design dengan alat ukur wound status continuum Bates Jensen Wound Assessment Tools. Sampel diambil dengan tehnik purposive sampling sebanyak 12 responden. Hasil penelitian didapatkan rata-rata usia responden 55 tahun dengan rerata nilai kadar gula darah sewaktu 298,25 mg/dL dan Hasil analisis bivariat rerata skor luka diabetik sebelum dan sesudah dilakukan intervensi menggunakan uji beda $T$ Test diperoleh nilai significancy 0,000 ( $p<0,005)$, sehingga dapat disimpulkan bahwa pemberian ekstra lidah buaya berpengaruh terhadap proses penyembuhan luka diabetik.
\end{abstract}

\section{Application of Aloe Vera for Diabetic Wound Healing}

Key Words:

Diabetes mellitus, Aloe vera, Footulcer

\begin{abstract}
Diabeticfootulcer has become a major health problem in Indonesia, this case is increasing, the ulcers are chronic and difficult to heal, it has infections and limb ischemia with the risk of amputation. If it is not threated nell, this condition can cause a decrease in productivity, disability, and early death. The purpose of this study was to determine how the effect of aloe vera extract on the process of healing diabetic ulcers on people with diabetes mellitus. This study was a quasi-experimental with one-group design pre-post test using wound status continuum the Bates Jensen Wound Assessment Tools. The samples were taken with purposive sampling technique of 12 respondents. Test analysis using the Paired t test. The result of showed the study average age of respondents was 55 years with an average value of blood sugar levels at $298,25 \mathrm{mg} / \mathrm{dL}$. The results of the bivariate analysis of mean diabetic wound scores before and after testing using the T test differed. The significance value of $0,000(p<0.005)$ it can be concluded that extra aplplication of help from aloe vera improve the process of healing diabetic ulcer.
\end{abstract}

\section{PENDAHULUAN}

Ulkus kaki diabetik(UKD) sampai saat ini menjadi masalah kesehatan utama di seluruh dunia, karena kasus yang semakin meningkat, Luka bersifat kronis dan sulit sembuh, menga- lami infeksi dan iskemia tungkai dengan risiko amputasi bahkan mengancam jiwa, membutuhkan sumber daya kesehatan yang besar, sehingga memberi beban sosio-ekonomi bagi pasien, masyarakat, dan negara. Peningkatan populasi 
PROFESI (Profesional Islam): Media Publikasi Penelitian

2019; Volume 17; No 1.

Website: ejournal.stikespku.ac.id

penderita diabetes mellitus (DM), berdampak pada peningkatan kejadian Luka kaki diabetik sebagai komplikasi kronis DM, dimana sebanyak 15-25\% penderita DM akan mengalami Luka kaki diabetik di dalam hidup mereka (Singhet.al., 2007).

Kemenkes (2013) menunjukkan menunjukkan bahwa terjadi peningkatan prevalensi Diabetes di Indonesia dari 5,7\% tahun 2007 menjadi 6,9\% atau sekitar sekitar 9,1 juta pada tahun 2013. Data International Diabetes Federation tahun 2015 menyatakan jumlah estimasi penyandang Diabetes di Indonesia diperkirakan sebesar 10 juta. Seperti kondisi di dunia, Diabetes kini menjadi salah satu penyebab kematian terbesar di Indonesia. Data Sample Registration Survey tahun 2014 menunjukkan bahwa Diabetes merupakan penyebab kematian terbesar nomor 3 di Indonesia dengan persentase sebesar 6,7. Bila tidak ditanggulangi, Kondisi ini dapat menyebabkan penurunan produktivitas, disabilitias, dan kematian dini.

Perawat mempunyai peran yang penting dalam merawat pasien DM yaitu dalam membuat perencanaan untuk mencegah timbulnya Luka diabetik dengan cara melakukan perawatan kaki, inspeksi kaki setiap hari. Tujuan utama pengelolaan ulkus kaki diabetik(UKD) yaituuntuk mengakses proses kearah penyembuhanluka secepat mungkin karena perbaikandari ulkus kaki dapat menurunkankemungkinan terjadinya amputasi dan kematianpasien diabetes. Secara umum pengelolaan ulkus kaki diabetik meliputi penanganan iskemia,debridemen, penanganan luka, menurunkantekanan plantar pedis (offloading),penanganan bedah, penanganan komorbiditas dan menurunkan risiko kekambuhanserta pengelolaan infeksi (Munro, ect. 2003). Penanganan Luka diabetik secara komprehensif diperlukan agar tidak menimbulkan gangren dan amputasi. Salah satu penanganan luka yang digunakan adalah perawatan luka teknik modern dengan menggunakan ekstrak lidah buaya (aloe vera). Lidah buaya mengandung beberapa zat seperti auksin, gibber-relin, antrakuinon, vitamin A, C, E yang telah terbukti khasiatnya sebagai antiinflamasi, antipiretik, antioksidan, antiseptik, antimikroba, serta antivirus. Lidah buaya mampu menembus dan meresap serta berdifusi secara baik sehingga mampu menahan hilangnya cairan tubuh dari permukaan kulit sehingga terjaga kelembabannya (Wijayakusuma, 2007), Permukaan yang lembab membuat epitel dari tepi luka lebih mudah migrasi ketempat luka sehingga proses migrasi epitel meningkat bersamaan dengan kontraksi miofibroblast yang akan menutup luka sehingga kecepatan penyembuhan luka semakin meningkat. Prinsip dari produk perawatan luka modern ini adalah mempertahankan dan menjaga lingkungan luka tetap lembap untuk memfasilitasi proses penyembuhan luka, mempertahankan kehilangan cairan jaringan dan kematian sel. Rohmawati,, dkk (2008) melakukan 3 penelitian tentang pemanfaatan gel Aloe vera untuk penyembuhan luka insisi dengan hasil bahwa ada pengaruh yang signifikan terhadap proses penyembuhan luka insisi dengan menggunakan gel Aloe vera. Tujuan penelitian ini menganalisis pengaruh ekstrak lidah buaya terhadap proses penyembuhan luka diabetik.

\section{METODE PENELITIAN}

Penelitian ini merupakan penelitian kuantitatif menggunakan desain quasi ekperimen dengan pre - post test one group design. Analisis data menggunakan uji Paired T Test (Dahlan, 2015). Jumlah sampel dalam penelitian ini sebanyak 12 responden, pengambilan sampel secara purposive sampling. Metode Perawatan luka dengan menggunakan ekstra lidah buaya dilakukan setiap dua hari dengan intervensi sebanyak 3 kali. Alat pengumpul data pada penelitian ini menggunakan instrumen yang sudah baku, yaitu wound status continuum Bates Jensen Wound Assessment Tools. Unsur yang dikaji adalah : ukuran, kedalaman, tepi luka, undermining, tipe jaringan nekrotik, jumlah jaringan nekrotik, tipe eksudat, jumlah eksudat, warna kulit sekitar luka, jaringan edema perifer, indurasi jaringan perifer, jaringan granulasi, dan jaringan epitelisasi.Tempat penelitian ini dilakukan di Puskesmas banyuanyar Surakarta dan klinik Sehat Mumtaza Kalijambe Sragen.

Penelitian ini telah mendapatkan perijinan dari komite etik ITS PKU Muhammadiyah Surakarta dengan nomor 01/O.09/KEPK-LPPM. ITS.PKU/V/2019, bahwa responden sudah menyetujui dan memahami maksud tujuan penelitian. 


\section{HASIL DAN PEMBAHASAN}

\section{a. Hasil Penelitian}

Hasil analisis penelitian didapatkan:

Tabel 1. Karakteristik Responden

Berdasarkan Jenis Kelamin

\begin{tabular}{lrr}
\hline \multicolumn{1}{c}{ Variabel } & $\begin{array}{r}\text { Frekuensi } \\
\text { (f) }\end{array}$ & Presentase (\%) \\
\hline Jenis kelamin & & \\
Laki laki & 7 & 58,3 \\
Perempuan & 5 & 41,7 \\
\hline Total & 12 & 100 \\
\hline
\end{tabular}

Berdasarkan tabel 1. Diketahui bahwa sebagian besar responden berjenis kelamin lakilaki sebanyak $7(58,3 \%)$.

Skor karakteristik luka sebelum dan sesudah perawatan luka dengan menggunakan ekstra lidah buaya

Tabel 2. Skor Karakteristik Luka

\begin{tabular}{ll}
\hline Variabel & Deskripsi $(\mathrm{n}=12)$ \\
\hline Skor Luka Diabetik sebelum & $42,83(14,07)$ \\
Intervensi & \\
Skor Luka Diabetik setelah & $35,25(12,77)$ \\
Intervensi & \\
\hline
\end{tabular}

Berdasarkan tabel 2. Rata-rata skor luka diabetik sebelum dilakukan intervensi adalah 42,83. Rata-rata skor luka diabetik setelah diberikan intervensi yang pertama menjadi 40,50 dan rata-rata skor luka diabetik semakin menurun setelah dilakukan intervensi ke 3 yakni 35.25.

Tabel 3. Hasil Uji Paired T Test Sebelum dan Sesudah Intervensi

\begin{tabular}{|c|c|c|c|c|}
\hline & \multicolumn{4}{|c|}{ Paired Differences } \\
\hline & \multirow[t]{2}{*}{ Mean } & \multicolumn{2}{|c|}{$\begin{array}{c}95 \% \text { Confidence } \\
\text { Interval of the } \\
\text { Difference }\end{array}$} & \multirow[t]{2}{*}{$\begin{array}{c}\text { Sig. }(2 \\
\text { tailed })\end{array}$} \\
\hline & & Lower & Upper & \\
\hline $\begin{array}{l}\text { Skor luka } \\
\text { diabetik } \\
\text { sebelum } \\
\text { intervensi - } \\
\text { Skor luka } \\
\text { diabetik } \\
\text { setelah } \\
\text { intervensi }\end{array}$ & 7.583 & 5.512 & 9.655 & .000 \\
\hline
\end{tabular}

Hasil analisis bivariat rerata skor luka diabetik sebelum dan sesudah dilakukan intervensi menggunakan uji beda $T$ test diperoleh nilai significancy $0,000(\mathrm{p}<0,005)$. Nilai significancy tersebut memiliki makna secara statistik terdapat perbedaan rerata skor luka diabetik sebelum dan sesudah pemberian intervensi.

\section{Pembahasan}

Diabetes melitus (DM) didefinisikan sebagai suatu penyakit atau gangguan metabolisme kronis dengan multietiologi yang ditandai dengan tingginya kadar gula darah disertai dengan gangguan metabolisme karbohidrat, lipid dan protein sebagai akibat insufisiensi fungsi insulin. Insufisiensi insulin dapat disebabkan oleh gangguan atau defesiensi produksi insulin oleh sel-sel beta langerhans kelenjar pankreas, atau disebabkan oleh kurang responsifnya sel-sel tubuh terhadap insulin (Brunner \& Suddarth 2013). Pasien diabetes memiliki kecendrungan tinggi untuk mengalami ulkus kaki diabetik (UKD) yang sulit sembuh dan risiko amputasi pada tungkai bawah, keadaan ini memberi beban sosioekonomi baik bagi pasien dan masyarakat.

Patogenesis utama UKD yaitu neuropati, kemudian iskemia pembuluh darah perifer. Prevalensi neuropati perifer $23-50 \%$ pada pasien DM dan lebih dari 60\% UKD disebabkan neuropati yang berupaneuropati sensorik, motorik dan otonom. Hilangnya sensasi nyeri dan suhu akibat neuropatisensorikmenyebabkanhilangnya kewaspadaan terhadap traumaatau benda asing, akibatnya banyak lukayang tidak diketahui secara dini dan semakin memburuk karena terusmenerus mengalami penekanan. Kerusakan inervasi otot-otot intrinsik kaki akibat neuropati motorik menyebabkan ketidakseimbangan antara fleksi dan ekstensi kaki serta deformitaskaki, yang kemudian menyebabkan terjadinya perubahan distribusi tekanan pada telapak kaki yang selanjutnya memicu timbulnya kalus. Kalus yang tidak dikelola dengan baik akan menjadi sumber trauma bagi kaki tersebut. Neuropati otonom menyebabkan penurunan fungsi kelenjar keringat dan sebum. Kaki akan kehilangan kemampuan alami untuk melembabkan kulit, kulit menjadi kering dan pecah-pecah sehingga mudah terinfeksi (Bowering, 2001).

Penyakit arteri perifer adalah penyakit penyumbatan arteri di ektremitas bawah yang 
PROFESI (Profesional Islam): Media Publikasi Penelitian

2019; Volume 17; No 1.

Website: ejournal.stikespku.ac.id

disebakan oleh atherosklerosis. Gejala klinis yang sering ditemui pada pasien PAD adalah klaudikasiointermitten yang disebabkan oleh iskemia otot dan iskemia yang menimbulkan nyeri saat istirahat. Iskemia berat akan mencapai klimaks sebagai ulserasi dan gangren. Pemeriksaan sederhana yang dapat dilakukan untuk deteksi PAD adalah dengan menilai Ankle Brachial Indeks (ABI) yaitu pemeriksaan sistolik brachial tangan kiri dan kanan kemudian nilai sistolik yang paling tinggi dibandingkan dengan nilai sistolik yang paling tinggi di tungkai. Nilai normalnya adalah $0,9-1,3$. Nilai dibawah 0,9 itu diindikasikan bahwa pasien penderita DM memiliki penyakit arteriperifer.

Menurut penelitian Reiberhampir 45-60\% pasien ulkusdiabetikum mengalami neuropati. Neuropati yang paling sering menyebab kanulkus pada pasien DM adalah neuropati sensorik. ${ }^{13}$ Kehilangan sensasi dikaki menyebabkan pasien tidak dapat mengetahui dan merasakan apabila terjadi luka di kaki. Luka yang terlambat diketahui ini menyebabkan terjadi ulkusdia betikum. ${ }^{1}$ Neuropatilainnya adalah neuropatimotorik yang menyebabkan deformitas pada kaki dan bagian yang mengalami deformitas sering menjadi tempat terjadi ulkus berulang setelah ulkus sebelumnya sembuh. Selanjutnya neuropatiotonom sering menyebabkan kulit pasien ulkus kering dan retak. Keadaan tersebut merupakan media tempat mudahnya berkembangbiak bakteri. Menurut kepustakaan neuropati merupakan factor risiko terjadinya ulkusdiabetikum.

Luka diabetik adalah kematian jaringan yang disebabkan oleh penyumbatan pembuluh darah (ischemic necrosis) karena adanya mikroemboli aterotrombosis akibat penyakit vaskular perifer oklusi yang menyertai penderita diabetes sebagai komplikasi menahun dari diabetes. Luka diabetik dapat diikuti oleh invasi bakteri sehingga terjadi infeksi dan pembusukan, dapat terjadi disetiap bagian tubuh terutama di bagian distal tungkai bawah Penyebab Luka Diabetik (Brunner \& Suddarth, 2013).

Hasil penelitian terhadap 12 responden dengan diabetes mellitus disertai ulkus kaki diabetik didapatkan rata-rata skor pengkajian luka menggunakan wound status continuum Bates Jensen Wound Assessment Tools adalah sebanyak 42,83 . Pengkajian atau pengukuran dari karakeristik luka diabetik meliputi ukuran, kedalaman, tepi luka, undermining, tipe jaringan nekrotik, jumlah jaringan nekrotik, tipe eksudat, jumlah eksudat, warna kulit sekitar luka, jaringan edema perifer, indurasi jaringan perifer, jaringan granulasi, dan jaringan epitelisasi.

Salah satu faktor risiko terjadi ulkus diabetikum pada penderita penyakit DM adalah neuropati. Neuropati menyebabkan gangguan saraf motorik, sensorik dan otonom. Gangguan motorik menyebabkan atrofi otot, deformitas kaki, perubahan biomekanika kaki dan distribusi tekanan kaki terganggu sehingga menyebabkan kejadian ulkus meningkat. Gangguan sensorik disadari saat pasien mengeluhkan kaki kehilangan sensasi atau merasa kebas. Rasa kebas menyebabkan trauma yang terjadi pada pasien penyakit DM sering kali tidak diketahui. Gangguan otonom menyebabkan bagian kaki mengalami penurunan ekskresi keringat sehingga kulit kaki menjadi kering dan mudah terbentuk fissura. Saat terjadi mikrotrauma keadaan kaki yang mudah retak meningkatkan risiko terjadinya ulkus diabetikum (Hastuti.2008).Neuropati yang paling sering menyebabkan ulkus pada pasien DM adalah neuropati sensorik. Kehilangan sensasi di kaki menyebabkan pasien tidak dapat mengetahui dan merasakan apabila terjadi luka di kaki. Luka yang terlambat diketahui ini menyebabkan terjadi ulkus diabetikum. Neuropati lainnya adalah neuropati motorik yang menyebabkan deformitas pada kaki dan bagian yang mengalami deformitas sering menjadi tempat terjadi ulkus berulang setelah ulkus sebelumnya sembuh. Selanjutnya neuropati otonom sering menyebabkan kulit pasien ulkus kering dan retak. Keadaan tersebut merupakan media tempat mudahnya berkembangbiak bakteri (Hastuti. 2008)

Perawat mempunyai peran yang penting dalam merawat pasien DM yaitu dalam membuat perencanaan untuk mencegah timbulnya Luka diabetik dengan cara melakukan perawatan kaki, inspeksi kaki setiap hari. Penanganan Luka diabetik secara komprehensif diperlukan agar tidak menimbulkan gangren dan amputasi. Salah satu penanganan luka yang digunakan adalah perawatan luka teknik modern dengan menggunakan ekstrak lidah buaya (aloe vera). Lidah buaya mampu menembus dan meresap serta berdifusi secara baik sehingga mampu menahan hilangnya cairan tubuh dari permukaan kulit 
sehingga terjaga kelembabannya, Permukaan yang lembab membuat epitel dari tepi luka lebih mudah migrasi ketempat luka sehingga proses migrasi epitel meningkat bersamaan dengan kontraksi miofibroblast yang akan menutup luka sehingga kecepatan penyembuhan luka semakin meningkat.Prinsip dari produk perawatan luka modern ini adalah mempertahankan dan menjaga lingkungan luka tetap lembap untuk memfasilitasi proses penyembuhan luka, mempertahankan kehilangan cairan jaringan dan kematian sel (Wijayakusuma, 2007).

Lidah buaya mengandung senyawa nutrisi yang dapat dimanfaatkan untuk pengobatan dan penyembuhan dimana lidah buaya mengandung hormone pertumbuhan (human growth hormone). Senyawa yang berperan terhadap proses penyembuhan Luka diabetik antara lain Kromium, inositol, vitamin A, dan getah kering lidah buaya yang mengandung hypoglycemik. Kadar protein dalam lidah buaya secara kualitatif kaya akan asam amino esensial. Seperti diketahui, bahwa protein dalam tubuh berperan untuk pembentukan jaringan baru dan memperbaiki sel-sel tubuh yang rusak (Furnawanthi, 2008).Senyawasenyawa kimia lidah buaya disintesis di kulit pelepahnya. Kulit lidah buaya tersusun atas 15-18 lapisan sel yang terletak di antara kloroplas. Lapisan-lapisan tersebut mengandung kristal kalsium oksalat dan magnesium laktat. Kandungan senyawa kimia pelepah lidah buaya lebih dari 200 jenis. Bagian terbesar kandungan jel lidah buaya adalah air $(98,5 \%)$ dan kandungan karbohidratnya sebesar $0,3 \%$. Karbohidrat yang terkandung di dalam jel lidah buaya berupa pektin, hemiselulosa, glukomanan, asemanan, dan derivat manosa. Selain senyawa-senyawa tersebut, jel lidah buaya juga mengandung asamamino, lipid, sterol (lupeol, camperterol, b-sitoserol), tanin, dan beberapa enzim (Tjitrosoepomo, 2005).

Hasil uji statistik Paired sample T Test nilai responden sebelum dan sesudah dilakukan perawatan luka diabetik dengan menggunakan ekstrak lidah buaya diketahui nilai signifikasinya sebesar $0.000(<0.05)$, maka dapat disimpulkan ada pengaruh dalam penyembuhan luka diabetik pada perawatan luka dengan menggunakan ekstra lidah buaya.Berdasarkan hasil evaluasi pada perawatan luka dengan menggunakan ekstrak lidah buaya sebanyak 3 kali perawatan terdapat pengaruh pada tipe dan jumlah jaringan nekrosis, tipe dan jumlah eksudat, jaringan granulasi serta epitalisasi.
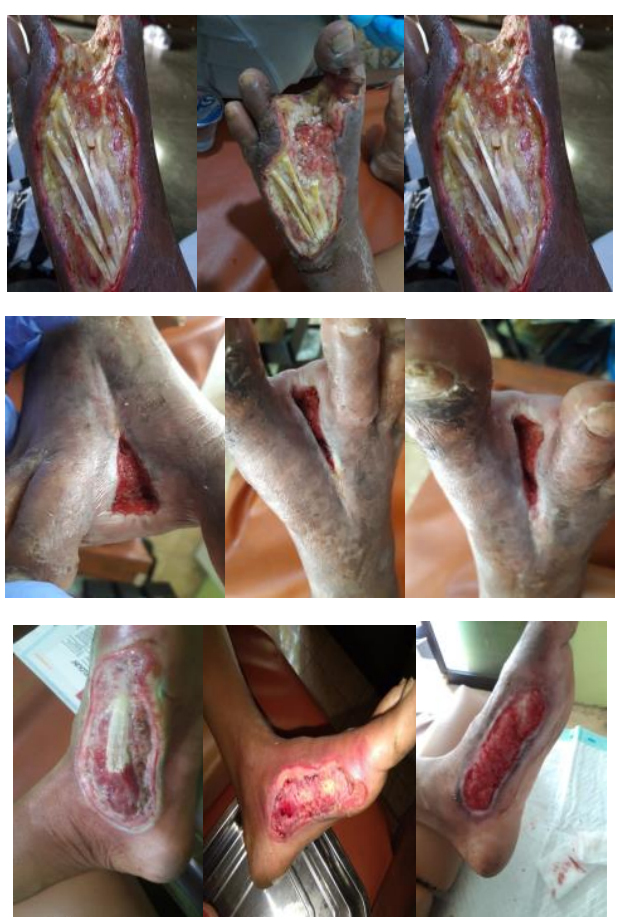

Gambar 1. Perkembangan Perawatan Ulkus Kaki Diabetic dengan Ekstrak Aloe Vera

Penanganan Luka diabetik secara komprehensif diperlukan agar tidak menimbulkan gangren dan amputasi. Salah satu penanganan luka yang digunakan adalah perawatan luka teknik modern dengan menggunakan ekstrak lidah buaya (aloe vera). Lidah buaya mampu menembus dan meresap serta berdifusi secara baik sehingga mampu menahan hilangnya cairan tubuh dari permukaan kulit sehingga terjaga kelembabannya (Wijayakusuma, 2007). Penelitian ini didukung dengan penelitian Aminanto,dkk (2015) yang menyatakan bahwa pemberian gel Aloe vera berpengaruh terhadap status luka diabetes daripada perawatan luka konvensional. Pengobatan dengan cara herbal atau tradisional pada penyakit diabetes berfungsi untuk menurunkan kadar gula darah, memperbaiki fungsi pankreas, membangun kembali sel dan jaringan pankreas yang rusak, meningkatkan efektivitas insulin serta menyembuhkan komplikasi diabetes mellitus. Salah satu herbal yang sesuai untuk diabetes, yaitu lidah buaya (aloe vera). Berdasarkan hasil penelitian, 
PROFESI (Profesional Islam): Media Publikasi Penelitian 2019; Volume 17; No 1.

Website: ejournal.stikespku.ac.id

tanaman ini kaya akan kandungan zat-zat seperti enzim, asam amino, mineral, vitamin, polisakarida dan komponen lain yang sangat bermanfaat bagi kesehatan. Selain itu, lidah buaya berkhasiat sebagai anti inflamasi, anti jamur, anti bakteri dan membantu proses regenerasi sel. Dapat menurunkan kadar gula dalam darah bagi penderita diabetes, mengontrol tekanan darah, menstimulasi kekebalan tubuh terhadap serangan penyakit kanker, serta dapat digunakan sebagai nutrisi pendukung penyakit kanker (Jatnika dan Saptoningsih, 2009).

\section{KESIMPULAN}

Hasil penelitian yang telah dilakukan dapat disimpulkan bahwa perawatan luka diabetik dengan menggunakan ekstrak lidah buaya memberikan pengaruh yang baik dalam proses penyembuhan luka kaki diabetik.

\section{REFERENSI}

Aminanto slamet, Ruhyana, Prihatiningsih Dwi. (2015). Efektifitas gel aloe vera sebagai primary dressing pada luka DM di Praktisi Perawatan Luka Indriyati Sleman, Yogyakarta. Skripsi. Stikes 'Aisyiyah Yogyakarta.

Bowering CCK. (2001). Diabetic foot ulcers pathophysiology, assessment and therapy. Canadian Family Phycisian ;47:1007-16.

Brunner \& Suddarth. (2013). Keperawatan Medikal Bedah edisi 12. Jakarta: EGC

Dahlan M. Sopiyudin. (2015). Statistik Untuk Kedokteran dan Kesehatan. Jakarta: Epidemiologi Indosenia
Furnawanthi, I. (2008). Khasiat dan Manfaat Lidah Buaya si Tanaman Ajaib. PT Agromedia Pustaka, Jakarta

Hastuti. (2008). Faktor-faktor risiko ulkus diabetika pada Penderita Diabetes Mellitus (Tesis). Semarang: Universitas Diponegoro

Jatnika, A. dan Saptoningsih. (2009). Meraup Laba dari Lidah Buaya. Jakarta: Agro Media Pustaka

Kementrian Kesehatan Republik Indonesia. (Kemenkes RI). (2013). RisetKesehatan Dasar/http://www.depkes.go.id/resources/ download/general/Hasil\%20Riskesdas\%2 02013.pdf. Diaksestanggal 18 Agutus 2019, 13:30 WIB

Munro N, Rich N, McIntosh C, FosterAVM, Edmonds ME. (2003). Infections in thediabetic foot: a practical management guide to foot care. British Journal of Diabetes \& Vascular Disease :3:1326

Reiber GE, Vileikyte I, Boyko EJ, Aguila MD, SmithDG. Lavery LA, Boulton AJM. (1999). Causal pathways forIncident lower extremity ulcer in Patients withDiabetes From two settings. Diabetes Care.

Singh, N., Armstrong, D.G., Lipsky, B.A. (2007). Preventing foot ulcers in patients with diabetes. Jama, 293:217-28

Tjitrosoepomo, Gembong. (2005). Taksonomi Tum-buhan Obat-Obatan. Gajah Mada University Press. Yogyakarta.

Wijayakusuma, Hembing. (2007). Penyembuhan dengan lidah buaya. Jakarta: Sarana Pustaka Prima. 